\title{
Dinamika Perkembangan Matematika Abad Pertengahan Hingga Munculnya Gerakan Renaissance (Implikasinya Terhadap Pembelajaran Matematika di Sekolah)
}

\author{
Yuni Arrifada, Dewi Rofiqoh, dan Kusaeri \\ Program Studi Pendidikan Matematika FTK UIN Sunan Ampel Surabaya, JL. A. Yani 117, Surabaya, \\ Jawa Timur, Indonesia, 60237
}

Korespondensi; Kusaeri, Email: kusaeri@uinsby.ac.id

\begin{abstract}
Abstrak
Islam pernah mencapai masa keemasan dengan lahirnya tokoh-tokoh muslim yang tidak hanya menguasai fiqih dan tafsir, tetapi juga ahli dalam matematika dan astronomi. Pemikirannya sangat mempengaruhi perkembangan matematika di dunia. Namun kini dunia Islam mengalami kemunduran dengan semakin tersisihnya tokoh matematikawan muslim oleh matematikawan dari barat (Eropa). Oleh karenanya, penelitian ini bertujuan: (1) menelusuri penyebab kemajuan perkembangan matematika di negara-negara Islam pada abad pertengahan, (2) mengungkap penyebab munculnya gerakan renaissance di Eropa, dan (3) mengungkap hikmah yang dapat diambil terhadap pembelajaran matematika di sekolah. Penelitian ini merupakan penelitian kepustakaan (library research), dengan data yang didapatkan dari buku-buku bacaan ilmiah, jurnal ilmiah, laporan penelitian, situs internet dan lainya yang relevan dengan sejarah matematika abad pertengahan dan zaman Renaissance. Data yang telah terkumpul, selanjutnya dilakukan pemilahan dengan cara organize, synthesize dan identify. Hasil penelitian menunjukkan: (1) penyebab kemajuan perkembangan matematika di negara-negara Islam pada abad pertengahan yakni gencarnya kegiatan penerjemahan karya-karya matematika asing dan dukungan yang luar biasa para khalifah pada pengkajian matematika, (2) munculnya gerakan renaissance di Eropa sebagai wujud pemberontakan masyarakat Eropa atas doktrin gereja yang melarang perkembangan ilmu pengetahuan sehingga masyarakat Barat banyak yang lari ke negara Islam untuk menyerap karya matematikawan muslim dan membuat gerakan renaissance, dan (3) berdasarkan dua peristiwa penting bisa diambil hikmah terhadap pembelajaran matematika di sekolah. Khususnya bagi para peserta didik dalam belajar matematika dengan mengadopsi semangat keilmuwan dan menamkan sikap pantang menyerah dan percaya diri.
\end{abstract}

Kata Kunci: Matematika; abad pertengahan; Renaissance

\begin{abstract}
Islam reach the golden era with the birth of Muslim figures who not only master of jurisprudence and interpretation, but also experts in mathematics and astronomy. The thinking is affecting the development of mathematics in the world. But now the Islamic world suffered a setback with the growing exclusion of Muslim mathematicians figure by mathematicians from the west (Europe). Therefore, this study aims to: (1) explore the causes of the progress of the development of mathematics in the Islamic countries in the Middle Ages, (2) reveal the causes of the emergence of a renaissance in Europe, and (3) reveals the lessons learned to the learning of mathematics in schools. This study is a literature study (library research), with data obtained from scientific reading books, scientific journals, research reports, and other internet sites relevant to the history of mathematics medieval and Renaissance. The data has been collected, then do the sorting by means organize, synthesize and identify. The results showed: (1) the cause of the progress of the development of mathematics in the Islamic countries in the Middle Ages the incessant activities of the translation of the works of mathematics and foreign outstanding support of the caliphs to the study of mathematics, (2) the emergence of a renaissance in Europe as a form of rebellion European societies over church doctrine that prohibits the development of science that many Western people who fled to the Islamic countries to absorb the Muslim mathematicians work and create a renaissance movement, and (3) based on two important events can take lessons on mathematics learning in school. Especially for learners in learning mathematics by adopting the spirit of science and menamkan perseverance and confidence.
\end{abstract}

Keywords: Mathematics; Middle Ages; Renaissance 


\section{Pendahuluan}

Matematika merupakan aspek yang unik dari hasil pemikiran manusia, dan sejarahnya berbeda dengan sejarah lainnya (Uta C. Merbach \& Carl B. Boyer, 2010 [6]). Matematika lahir dan berkembang sejak dimulainya peradaban manusia. Sejarah mencatat bahwa matematika telah banyak digunakan oleh masyarakat sejak zaman dahulu, meskipun dalam bentuk yang paling sederhana seperti membilang atau mengukur (Gatot Muhsetyo, 2012 [2]). Hal ini menunjukkan bahwa matematika muncul sebagai solusi di tengah-tengah permasalahan kehidupan sosial masyarakat.

Sejarah berkembangnya matematika menunjukkan bahwa ada interaksi yang nyata antara matematika dan aplikasinya (Budi Martiyasa [1]). Artinya banyak ide-ide matematika yang dikembangkan dari konteks nyata yang melingkupi masyarakat waktu itu. Sebagai contoh geometri (Dwi Mulyo, 2000 [12]). Cabang matematika ini berkembang dari zaman Mesir kuno, di mana banyak petani mengukur tanah garapannya di sekitar sungai Nil, yang hampir tanah garapanya berbentuk segitiga. Proses ini melahirkan cara bagaimana mengukur luas segitiga. Dari pengalaman empiris ini, berkembang ke bangun datar lain.

Ilustrasi tersebut menunjukkan, walaupun matematika sepertinya hasil imajinasi akal atau pemikiran manusia, namun matematika juga tidak lepas dari konteks kehidupan (empiris) (Van Melsen, 1985 [442]). Namun, empirisme di dalam matematika sangat berbeda dengan empirisme pada ilmu-ilmu lainnya (terutama ilmu-ilmu alam). Salah satu alasannya, relasi-relasi kuantitatif dalam matematika dapat dimengerti dengan mengabstraksikannya dari berbagai macam pengalaman, lalu mengolahnya lebih lanjut secara intelektual, pada akhirnya bisa terlepas dari pengalaman tersebut (abstraksi).

Abstraksi matematika terus mengalami perkembangan yang pesat pada abad pertengahan. Pada periode ini berlangsung aktivitas intelektual yang menakjubkan dengan pusat peradaban dikendalikan kaum Muslim. Kaum Muslim memegang kepemimpinan kebangkitan intelektual yang bahkan lebih cepat dibandingkan apa yang dilakukan orang-orang Yunani ribuan tahun sebelumnya.

Abad X Masehi merupakan puncak pembangunan daulah Islamiyah. Dunia Muslim, mulai dari Cordova di Spanyol sampai ke Multan Pakistan, mengalami kemajuan di bidang matematika (Machfud Syaefudin, 2013 [73-74]). Umat Islam sangat peduli terhadap ilmu Pengetahuan. Kegandrungan terhadap ilmu ini menelurkan generasi emas para pemikir hebat dan ilmuwan Muslim dalam bidang matematika (Yusuf Effendi, 2015).

Pada masa ini matematika dianggap sebagai ilmu terpenting karena menjadi dasar bagi semua ilmu. Matematika dijadikan sebagai bahasa ilmu pengetahuan, sesuai dengan pemikiran Aristoteles (Eko Laksono dalam Supriyadi, 2015 [182]). Matematika memperoleh perhatian istimewa. Hampir semua sarjana Muslim dari berbagai jenis disiplin ilmu memiliki penguasaan dan apresiasi yang amat tinggi terhadap matematika (Husain Heriyanto, 2015 [182]). Pada masa dinasti Abbasiyah di bawah kepemimpinan Al-Manshur, dilakukan langkah strategis berupa penerjemahan literatur-literatur asing dari Yunani, Amarik, dan India ke dalam bahasa Arab. Berbekal karya-karya terjemahan itu, para cendikiawan Muslim mengembangkannya menjadi penemuan-penemuan baru (Yusuf Effendi, 2015 [238-239]).

Langkah strategis berikutnya dilakukan pemerintahan Harun ar-Rasyid dan anaknya Khalifah alMamun. Pada masa ini didirikan perpustakaan terbesar di dunia sekaligus lembaga riset Bayt alHikmah di Baghdad. Perpustakaan ini dipenuhi ribuan buku ilmu pengetahuan (Badri Yatim, 2007 [279]). Di Bayt al-Hikmah disimpan buku-buku yang bervariasi, antara lain kitab sejarah Islam dan Nabi, buku terjemah, buku ilmiah dan falak, buku kimia, kedokteran, filsafat, sastra dan matematika. $\mathrm{Hal}$ ini memberikan dampak munculnya ilmuwan-ilmuwan Muslim yang sangat produktif (Machfud Syaefudin, 2013 [68]).

Smith berpendapat bahwa dunia berhutang besar kepada ilmuwan Muslim karena melindungi karya klasik matematika Yunani. Mereka juga membuat kemajuan besar dalam bidang aljabar dan menunjukkan kejeniusan karya mereka dalam bidang trigonometri (David E. Smith, 1958). Yushkevich berpendapat bahwa ilmuwan Muslim memiliki pengaruh besar dalam perkembangan matematika di Eropa, memperkaya dengan temuan mereka sendiri dan temuan yang diwariskan oleh bangsa Babilonia, Yunani, India dan lain-lain.

Pada akhir abad XI, matematika di negara Muslim mengalami kemunduran. Penyebabnya adalah: (1) peristiwa terbakarnya perpustakaan Kordova yang menjadi tempat diletakkannya hasil pemikiran cendekiawan-cendekiawan Muslim dalam berbagai bidang ilmu pengetahuan, termasuk matematika. 
Terbakarnya perpustakaan Kordova merupakan pukulan yang telak. Sebab dari peristiwa ini, seluruh buku hasil peninggalan cendekiawan Muslim yang belum sempat diperbanyak habis terbakar. Penggandaan buku belum dilakukan karena saat itu mesin cetak belum ditemukan; dan (2) negara tidak sanggup memberikan fasilitas kepada warga negaranya untuk melakukan riset-riset yang dapat membantu perkembangan matematika. Ketidakmampuan ini sebagai akibat dari kemiskinan yang melanda Timur Tengah setelah penyerangan yang dilakukan oleh umat Kristiani terhadap umat Islam.

Di tengah kemunduran matematika di negara Islam, di Eropa mengalami hal yang sebaliknya. Terutama setelah adanya gerakan Renaissance. Renaissance lahir tatkala kaum intelektual, politik, dan seniman di daratan Eropa serentak bertekad untuk mengadakan suatu gerakan pembaharuan yang menginginkan kebebasan berpikir untuk merubah doktrin agama yang dirasakan sangat mengekang (Yusuf Effendi, 2015 [350]).

Saat yang bersamaan, banyak cendekiawan Bizantium (Romawi Timur) yang berpindah ke berbagai negara di Eropa dengan membawa buku-buku matematika, baik yang berbahasa Yunani maupun Arab. Inilah yang kemudian menjadi rujukan bagi bangsa-bangsa Eropa untuk mengembangkan matematika selama abad berikutnya. Di bawah pimpinan Gerard Cremona mereka mempekerjakan guru, sarjana, dan penduduk asli Arab untuk mulai menerjemahkan buku-buku matematika berbahasa Arab yang ditulis oleh cendikiawan Muslim.

Berdasarkan uraian diatas, tulisan ini akan berupaya mengidentifikasi penyebab kemajuan perkembangan matematika di negara-negara Islam pada abad pertengahan, dan munculnya gerakan renaissance. Berdasarkan dua masalah tersebut, dapat diambil hikmah terhadap pembelajaran matematika di sekolah/madrasah.

\section{Metode}

Studi ini merupakan studi kepustakaan (/ibrary research). Dalam penelitian jenis ini, dikaji secara kritis pengetahuan, gagasan, atau temuan yang terdapat di dalam tubuh literatur berorientasi akademik (academic-oriented literature), serta merumuskan kontribusi teoritis dan metodologisnya untuk topik tertentu (Cooper dan Taylor dalam Mohammad Imam Farisi, 2010). Sumber data penelitian ini berupa dokumen sekunder yang didapatkan dari buku-buku bacaan ilmiah, jurnal ilmiah, laporan penelitian, situs internet dan lainya yang relevan dengan sejarah matematika abad pertengahan dan zaman Renaissance.

Data yang telah terkumpul, selanjutnya dilakukan pemilahan dengan cara berikut. Pertama, organize yakni mengorganisasi literatur yang di-review. Literatur yang di-review merupakan literatur yang relevan/sesuai dengan permasalahan. Tahap dalam mengorganisasi literatur adalah mencari ide, tujuan umum, dan simpulan dari literatur dengan membaca abstrak, beberapa paragraf pendahuluan, dan kesimpulannya, serta mengelompokkan literatur berdasarkan kategori-kategori tertentu. Kedua, synthesize yakni menyatukan hasil organisasi literatur menjadi suatu ringkasan agar menjadi satu kesatuan yang padu, dengan mencari keterkaitan antar literatur. Ketiga, identify yakni mengidentifikasi isu-isu kontroversi dalam literatur. Isu kontroversi yang dimaksud adalah isu yang dianggap sangat penting untuk dikupas atau dianalisis, guna mendapatkan suatu tulisan yang menarik untuk dibaca.

\section{Hasil dan Pembahasan}

Kajian matematika secara ilmiah dimulai sejak umat manusia bersentuhan dengan beberapa karya matematika yang dihasilkan oleh peradaban lain seperti Yunani, India dan Cina. Pemikiran bangsa Yunani sangat menonjol dengan ide-ide briliannya, mengispirasi bangsa lain dalam mengembangkan matematika. Pengaruh Yunani dalam matematika masuk melalui kegiatan penerjemahan. Pada saat itu, umumnya matematika bukan hanya berperan sebagai alat perkembangan budaya, akan tetapi matematika sendiri lahir dan berkembang oleh adanya suatu budaya (Sukardjono, 2011).

Matematika Yunani membawa pengaruh pada perkembangan matematika di dunia Islam. Tersebarnya matematika Yunani ke penjuru Islam dikarenakan orang-orang Kristen Ortodoks menerapkan pemisahan sekte-sekte karena alasan perbedaan doktrinal. Orang Kristen yang berada di bawah doktrin gereja mengucilkan orang-orang yang berbeda pendapat. Karena paksaan para pendeta, 
mereka akhirnya pindah ke negara Arab dan Persia dengan membawa warisan ilmu pengetahuan terutama kedokteran, matematika, astronomi, teknologi dan filsafat (Mehdi Nakosteen, 1996).

Kondisi ini tentu membawa dampak bagi perkembangan matematika di Arab dan Persia. Perkembangan ini terjadi hingga Islam datang. Di bawah kekuasaan Bani Umayyah, kegiatan penerjemahan buku-buku matematika dilakukan. Namun, karya-karya yang diterjemahkan jumlahnya sangat terbatas. Hal ini disebabkan kebijakan pemerintahan Bani Umayyah lebih diorientasikan pada pengembangan (expansi) wilayah kekuasaan dan pembangunan infrastruktur kepemerintahan (Agus Rifai, 2014 [66]). Penerjemahan pada masa ini dilakukan secara bertahap. Pada awalnya karya-karya asing atau Yunani diterjemahkan ke dalam bahasa Syiria, kemudian diterjemahkan ke dalam bahasa Arab.

Puncak kegiatan intelektual terjadi pada masa pemerintahan Abbasiyah di bawah pimpinan khalifah Harun al Rasyid dan putranya al Mamun. Masa pemerintahan Harun al Rasyid yang berkuasa selama 23 tahun ini merupakan permulaan zaman keemasan (golden ages of Is/am) bagi sejarah dunia Islam di belahan Timur (M. Mukhlis Fahruddin, 2009 [181]). Khalifah Harun al Rasyid dan al Mamun terkenal sebagai khalifah yang cinta terhadap ilmu pengetahuan. la menggalakkan penerjemahan bukubuku asing ke dalam bahasa Arab sehingga masyarakat muslim mampu mencerna isi buku tersebut. Ilmu matematika terbaik dari seluruh peradaban besar dunia seperti Yunani, Mesopotamia, Mesir, Persia, India dan Cina semuanya dikumpulkan untuk diterjemahkan.

Di dalam istana, khalifah Harun al Rasyid sering mengundang para ilmuwan untuk diajak berdiskusi tentang berbagai ilmu pengetahuan. Buku-buku matematika hasil terjemahan dikaji dan didiskusikan secara mendalam kemudian dianalisis, dikembangkan untuk mendapatkan berbagai varian ilmu baru. Inilah tradisi yang paling berpengaruh dalam menciptakan tradisi keilmuwan yang kondusif yakni adanya gerakan penerjemahan. Melalui kegiatan inilah, abad penerjemahan yang telah meletakkan dasar abad pencerahan pengetahuan Islam di dunia Timur.

Kegiatan penerjemahan ini merupakan konsekuensi logis dari adanya kontak kebudayaan antara masyarakat Muslim dengan kebudayaan asing (Poeradisastra dalam Agus Rifai, 2014 [64]). Gerakan penerjemahan berlangsung dalam tiga fase (M. Mukhlis Fahruddin, 2009 [186]). Fase pertama berlangsung pada masa khalifah al Mansur dan putranya (Harun al Rasyid) dengan menerjemahkan karya-karya dalam bidang astronomi dan manthiq. Fase kedua berlangsung pada masa pemerintahan khalifah al Mamun. Kegiatan penerjemahan buku dilakukan dalam bidang filsafat dan kedokteran. Kegiatan penerjemahan pada fase kedua berakhir hingga tahun $300 \mathrm{H}$. Memasuki tahun $300 \mathrm{H}$, fase ketiga berlangsung dan bidang ilmu pengetahuan yang semakin meluas.

Adanya teknologi pembuatan kertas yang dipelopori oleh Cina turut mengiringi kemajuan matematika. Hal ini juga tidak lepas dari kontribusi ahli pikir dan para khalifah yang gemar menggali pemikiran-pemikiran besar dari berbagai peradaban yang telah lalu. Mereka sering mendiskusikan pemikiran-pemikiran filsuf Yunani yang mengembangkan matematika seperti Plato dan Aristoteles.

Para ilmuwan Muslim yang telah mengkaji, meneliti dan menganalisis tentang objek matematika menghasilkan berbagai pemikiran selanjutnya ditulis pada sebuah buku. Karya-karya mereka yang telah dibukukan kemudian digandakan dan disebarkan pada semua khalayak. Buku-buku matematika pun dengan cepat menyebar ke seluruh dunia Islam. Budaya menulis ini memberikan nuansa ilmiah yang khas (M. Mukhlis Fahruddin, 2009 [186]).

Buku-buku hasil terjemahan ini disimpan di perpustakaan Bayt al Hikmah yang digunakan sebagai pusat penerjemahan dan tempat untuk berdiskusi. Seiring dengan kemajuan pemerintahan khalifah al Mamun, Bayt al Hikmah menjadi kebanggaan Bani Abbasiyah yang memuat hasil-hasil peradaban dan kebudayaan umat manusia di belahan dunia. Perpustakaan Bayt al Hikmah mengumpulkan berbagai literatur ilmu pengetahuan yang tidak saja terbatas pada karya-karya bahasa Arab, akan tetapi juga karya-karya asing yang berasal dari luar Arab (Agus Rifai, 2014 [88]).

Tradisi berdiskusi terus berkembang. Adanya Bayt al Hikmah sebagai tempat berkumpul untuk bertukar pikiran dan berdebat masalah keilmuwan membantu dalam menciptakan suasana keilmuwan yang kondusif (Ibrahim Hasan,1989, [133]). Dari diskusi ini muncullah berbagai pemikiran kreatif untuk mengembangkan dan menciptakan matematika dari para ilmuwan Muslim. Hal ini ditunjang pula dengan didirikannya observatorium di Baghdad pada masa Khalifah al Mamun dan di Damaskus oleh khalifah Harun al Rasyid. Tempat ini menjadi bukti terjadinya penelitian yang tinggi dalam bidang astronomi dan matematika, karena dalam perkembangannya kedua disiplin ilmu ini senantiasa berkaitan. Sehingga banyak pakar astronomi di dunia Muslim dan juga pakar dibidang matematika. 
Seperti Al Khawarizmi, Ibnu Abu Ubaida dari Valencia, Maslama al Majriti dari Andalusia dan Umar Khayyam. Mereka adalah ahli matematika yang juga seorang astronom.

Bila ditarik kesimpulan, satu penyebab kemajuan perkembangan matematika dalam imperium Islam adalah terciptanya gairah mencari ilmu. Akibat didirikannya pabrik kertas di Baghdad, pemikiran dan penemuan para ilmuwan matematika dapat dibukukan dengan baik. Untuk menunjang sistem pendidikan maka buku-buku matematika karya para ilmuwan matematika tersebar luas dan dapat diakses dengan mudah oleh masyarakat Islam kala itu. Bahkan keadaan ini mendorong orang Barat untuk berkunjung dalam rangka menyambut ilmu pengetahuan di dunia Islam. Pada saat yang sama, kaum intelektual menjadi kaum yang paling dihormati dan diistimewakan.

\section{Munculnya Gerakan Renaissance di Eropa}

Pada abad XII, kejayaan keilmuan di dunia Islam mulai mengalami penurunan. Hal ini berakibat pada perkembangan matematika yang semakin surut di negara-negara Islam. Dengan hancurnya Baghdad dan Granada di Spanyol sebagai pusat pendidikan dan kebudayaan Islam menandai runtuhnya sendisendi pendidikan dan kebudayaan Islam. Musnahnya lembaga pendidikan dan semua buku-buku ilmu pengetahuan dari kedua pusat pendidikan di dunia Islam, menyebabkan pula kemunduran pendidikan di seluruh dunia Islam (Zuhairini, 1992 [111]).

Masa kejayaan Islam yang berbuah manis pada lahirnya beragam ilmu pengetahuan dan semakin berkembangnya matematika akhirnya diserap oleh masyarakat Eropa sehingga terjadi transformasi intelektual dari dunia Islam di Timur ke dunia Barat, Eropa. Peralihan perkembangan ilmu pengetahuan tersebut dimulai pada tahun 1085 M, yakni ketika Kota Toledo direbut oleh Raja Alfonso VI yang beragama Kristen. Akibatnya, hilanglah pusat sekolah tinggi dan ilmu pengetahua (Sri Suyanta, 2011 [27]).

Pada tahun $1236 \mathrm{M}$, Cordoba sebagai pusat kegiatan intelektual jatuh ke tangan Raja Alfonso VII. Dengan ini maka hilang pula pusat kebudayaan Islam di Barat. Kehilangan ini terus berlanjut pada kota-kota besar lainnya seperti Sevilla, Malaga dan Granada. Akhirnya umat Islam harus meninggalkan tanah airnya yang telah dibangun selama 8 abad dan meninggalkan segala macam kemajuan, baik kemajuan peradaban maupun ilmu pengetahuan (Sri Suyanta, 2011 [27]).

Sementara itu, Baghdad sebagai pusat peradaban Islam di dunia Timur juga mengalami kehancuran akibat serangan dari tentara Mongol. Pada abad ke-13 M mengiringi kehancuran ibukota, hegemoni negara Arab mulai redup untuk selamanya. Banyak wilayah-wilayah jajahan dan peradaban yang telah lama kokoh (mulai dari Cina sampai Eropa) hancur di tangan bangsa Mongol. Selama periode ini mereka tidak hanya ingin menguasai peradaban yang telah dibangun oleh dinasti Abbasiyah, tetapi juga terlibat aktif dalam menghancurkan struktur-struktur penting yang merupakan warisan intelektual pada masa keemasan Islam.

Usaha penghancuran bangsa Mongol mencakup perusakan kota-kota dan tempat-tempat pendidikan, pembantaian guru dan ilmuwan matematika. Konsekuensi dari keadaan ini, kehidupan masyarakat begitu terganggu dan memperlambat perkembangan peradaban. Tidak hanya pusat-pusat studi yang dirusak dan ilmuwan yang dibunuh atau dibuat panik dan ketakutan yang mendalam. Tetapi juga semua tempat yang nyaman untuk penciptaan ilmu pengetahuan juga diganggu (Farid Hasyim, 2012 [10-11]).

Efek yang sama juga dirasakan oleh umat muslim dengan adanya perang salib. Perang salib menggambarkan reaksi orang Kristen di Eropa terhadap umat Muslim di Asia yang telah menguasai wilayah Kristen sejak tahun $632 \mathrm{M}$. Militer Kristen menjadikan salib sebagai simbol yang menunjukkan bahwa perang ini suci dan bertujuan membebaskan kota suci Baitul Maqdis (Jerussalem) dari orangorang Islam (Samsul Munir Amin, 2015 [408-409]). Seperti halnya bangsa Mongol, tentara salib juga menghancurkan kota-kota Muslim. Teror dan pembunuhan mengganggu ketenangan penduduk dan tempat-tempat yang kondusif bagi perkembangan ilmu pengetahuan termasuk matematika di dunia Muslim mengalami kemandekan.

Invasi bangsa Mongol dan invasi tentara salib merupakan faktor eksternal yang menjadi hambatan kemajuan ilmu pengetahuan dan matematika di dunia Muslim. Sedangkan dari sisi internal adalah kegagalan para pemimpin dalam memanfaatkan berbagai disiplin ilmu pengetahuan. Para ilmuwan dan ahli matematika kurang mendapat perhatian dari para khalifah untuk mengembangkan 
penemuannya. Disamping itu pada puncak kegiatan intelektual di bawah khalifah al Mamun telah didirikan perpustakaan dan observatorium bagi perkembangan ilmu pengetahuan dan matematika, tetapi sayangnya tidak dilanjutkan oleh khalifah-khalifah berikutnya.

Pada abad ke-14 bangsa Eropa ingin membebaskan diri dari zaman kegelapan dengan melakukan revolusi intelektual untuk bangkit mengejar kemajuan di Eropa melalui gerakan renaissance. Istilah renaissance (bahasa Perancis) berasal dari kata rinascita (bahasa Italia) yang berarti kelahiran kembali. Istilah ini pertama kali diperkenalkan oleh Giorgio Vasari untuk menggambarkan semangat keilmuan Italia mulai abad ke-14 (Sutarjo Adisusilo, 2013 [67]). Secara etimologi renaissance berasal dari bahasa latin yaitu re berarti kembali dan naitre berarti lahir. Secara umum renaissance dapat diartikan sebagai masa peralihan antara abad pertengahan ke abad modern yang ditandai dengan lahirnya berbagai kreasi baru yang diilhami oleh kebudayaan Eropa klasik (Yunani dan Romawi) yang lebih bersifat duniawi (Saifullah, 2014 [133]).

Renaissance dimulai di Italia, kemudian menyebar keseluruh Eropa. Terdapat dua alasan dipilihnya Italia sebagai negara pelopor lahirnya renaissance (Mc Graw Hill, 2006 [305]). Pertama, Italia merupakan satu-satunya negara yang tidak mengalami dampak buruk akibat peperangan melawan umat Islam. Kedua, perekonomian Italia tidak terhubung langsung dengan negara-negara lain yang pada abad pertengahan dikuasai oleh umat Islam, sehingga dapat dikatakan bahwa perokonomian Eropa tetap stabil. Dari kedua alasan tersebut, Italia layak digunakan sebagai tempat berkembangnya ilmu pengetahuan sekaligus memberikan dukungan finansial kepada ilmuwan-ilmuwan yang ingin mengembangkan ilmu pengetahuan bagi Eropa (Zamrotul Faiqoh, 2013 [39]).

Munculnya gerakan renaissance sebagai bentuk kekecewaan kaum intelektual Barat atas doktrin gereja yang mencengkeran manusia dalam menata kehidupan. Gerakan renaissance juga menimbulkan peralihan perkembangan ilmu pengetahuan dari dunia Timur ke dunia Barat (Eropa).

Setelah berakhirnya masa kekuasaan Islam di Andalusia, para penduduk asli Andalusia yang menjadi intelektual seperti guru, dokter, ahli matematika dan filsafat yang pernah bekerjasama dengan umat Islam ditugaskan untuk tetap menjalankan tugasnya. Namun harus mengganti namanya dan berpindah keyakinan menjadi kristiani. Mereka mendapat tugas untuk menerjemahkan bidang ilmu yang kuasai kedalam bahasa selain bahasa Arab agar dapat dipahami oleh orang-orang Eropa (Sri Suyanta, 2011 [28]).

Kebangkitan intelektual dalam bidang matematika di Eropa didukung dengan banyaknya pemuda Eropa yang menuntut ilmu ke perguruan tinggi pada masa keemasan Islam. Selanjutnya mereka menyerap ilmu pengetahuan karya matematikawan Muslim melalui gerakan penerjemahan ke dalam bahasa Latin. Orang-orang Mozareb sangat berperan dalam menerjemahkan karya-karya matematikawan Muslim yang berbahasa Arab kedalam bahasa Latin, karena mereka menguasai kedua bahasa tersebut dengan baik.

Di Toledo didirikan Sekolah Tinggi Terjemahan yang dipimpin oleh Raymon untuk memudahkan penyerapan ilmu-ilmu Arab dan menggalakkan kegiatan penerjemahan buku-buku bahasa Arab kedalam bahasa Latin. Penerjemah-penerjemah di Baghdad banyak yang pindah ke Toledo, terutama yang berasal dari Yahudi. Mereka rata-rata menguasai bahasa Arab, Yahudi, Spanyol dan Latin (Musyrifah Sunanto, 2011 [239]).

Penerjemahan buku-buku matematika ke dalam bahasa Latin dipimpin oleh Gerard dari Cremona. Buku-buku matematika yang diterjemahkan menyimpan banyak temuan matematikawan Muslim yang akhirnya dimanfaatkan oleh bangsa Eropa. Dalam bidang geometri, Gerard menerjemahkan buku-buku Euclid yang mencapai Eropa melalui penerjemahan dari bahasa Arab.

\section{Lesson Learn yang Dapat Diambil terhadap Pembelajaran Matematika}

Mengaca dari kejadian yang terjadi pada dua periode di atas (abad pertengahan sebagai masa kejayaan Islam dan renaissance) dapat dijadikan rujukan bahwa pada masa itu penghargaan terhadap pemikiran dan buah pikir para ilmuwan mendapat apresiasi yang luar biasa. Untuk menunjang kegiatan intelektual tersebut, para pemimpin yang juga cinta terhadap ilmu pengetahuan, menggalakkan pembangunan perpustakaan yang sangat pesat di tengah-tengah masyarakat. Keberadaan perpustakaan berkembang fungsinya menjadi lembaga yang berperan menyimpan dan melestarikan beragam ilmu pengetahuan 
sebagai khazanah umat Islam dan perpustakaan juga melakukan kegiatan pengelolaan serta penyebarluasan ilmu pengetahuan bagi kemaslahatan umat manusia.

Dengan menggali kembali sejarah tentang kegiatan keilmuan dan peran perpustakaan di masa keemasan Islam diharapkan perpustakaan-perpustakaan di sekolah atau madrasah mampu mengembangkan perpustakaan sebagaimana fungsi dan peran perpustakaan yang terdapat di negara Islam. Di lembaga pendidikan, pengajar dan pelajar harus betul-betul memanfaatkan perpustakaan dengan baik. Keberadaan perpustakaan menjadi tempat penyimpanan buku-buku hasil karya manusia hingga selanjutnya dikembangkan dan dibaca oleh generesi berikutnya. Di tempat ini mereka tidak hanya saling bertukar ilmu pengetahuan tetapi juga bisa digunakan sebagai tempat untuk membuat penyelidikan lanjutan atau penelitian. Kolaborasi antara pengajar dan pelajar dalam melakukan penelitian akan menambah koleksi perpustakaan sebagai tempat penyedia informasi bagi siswa di sekolah.

Tidak hanya terbatas untuk konsumsi pelajar dan pengajar di lingkungan sekolah, perpustakaan juga bisa dibangun untuk umum seperti perpustakaan yang terdapat di setiap wilayah, pusat peradaban manusia berlangsung. Terbuka bagi semua orang dengan berbagai latar belakang yang berbeda-beda. Mereka memiliki kebebasan untuk membaca dan menyalin naskah-naskah yang diperlukan. Dengan berjalannya kegiatan tersebut, perpustakaan tidak hanya berfungsi sebagai gudang penyimpanan buku, namun juga akan menjadi perpustakaan yang aktif (working libraries).

Meninjau peran penting perpustakaan di masa kejayaan Islam, perpustakaan-perpustakaan umum juga memberikan ruang untuk pengembangan bebagai bidang literatur dan ilmu pengetahuan. Dengan demikian masyarakat lebih mudah untuk mendapatkan koleksi-koleksi buku dalam berbagai bidang akademis. Mengaca pada kemegahan Bayt al Hikmah yang memilki staf sejumlah cendikiawan Muslim dan non Muslim sangat penting dijadikan rujukan terhadap perkembangan perpustakaan di Indonesia yang multikultural.

Sebaliknya, dari gerakan renaissance dapat diambil pelajaran bahwa pengekangan berpikir pada diri anak akan membuat anak terbelenggu. Bila hal ini terjadi, maka kreativitas siswa sekolah/madrasah cenderung akan mati. Dalam konteks pembelajaran matematika, pemberian soal matematika yang bersifat konvergenlah (soal yang menuntut jawaban seragam) yang menjadi pemicu. Sebab, anak selalu dipaksa menjawab soal yang harus sama dengan yang dipikirkan atau diajarkan guru.

Ilustrasi berikut kiranya dapat memperjelas, apa yang masih sering dijumpai di kelas-kelas pembelajaran matematika-baik di sekolah umum ataupun madrasah. Misalnya, dalam suatu pembelajaran matematika tidak jarang guru melempar suatu pertanyaan yang harus dijawab siswa. Ada seorang siswa yang berani menjawab pertanyaan dengan penuh keyakinan dan harapan mendapat simpati guru. Apa yang terjadi justru di luar dugaan. Dengan jawaban itu teman-temannya di sekitar tertawa sedang guru mengatakan, Tidak, itu salah. Sebab cara yang kamu lakukan berbeda dengan yang Bapak/lbu jelaskan minggu kemarin. Mendapati hal semacam ini, bagi anak merupakan tamparan yang luar biasa, dan merupakan awal terbentuknya citra negatif pada diri anak. Sejak saat itu, belajar matematika menjadi tugas sangat berat baginya. Keraguan tumbuh dalam dirinya, sebab dia merasa malu dan dipermalukan dihadapan banyak teman lainya. Kesan negatif ini terus membayangi dalam perkembangan dirinya ketika belajar matematika selanjutnya lantaran komentar itu.

\section{Kesimpulan}

Berdasakan uraian sebelumnya, maka dapat ditarik simpulan sebagai berikut:

1. Penyebab kemajuan perkembangan matematika pada abad pertengahan yakni terciptanya semangat mencari ilmu dari masyarakat muslim dengan digalakkannya kegiatan penerjemahan terhadap karyakarya matematika asing dan dukungan penuh dari sang khalifah pada kegiatan intelektual sehingga ilmu matematika, sebagai warisan budaya bangsa terdahulu dapat dikembangkan menjadi bidang keilmuwan baru dengan lahirnya para matematikawan muslim.

2. Munculnya gerakan renaissance di Eropa akibat doktrin gereja sehingga membuat ilmuwan Barat banyak yang lari ke negara-negara Islam untuk menyerap karya-karya matematikawan Muslim melalui kegiatan penerjemahan untuk dipelajari dan dikembangkan hingga saat ini.

3. Dampak/hikmah yang dapat diambil terhadap pembelajaran matematika di sekolah adalah semangat para matematikawan dalam mengkaji ilmu matematika perlu ditularkan kepada para pelajar melalui 
kegiatan belajar matematika yang secara tidak langsung menanamkan sikap pantang menyerah dan percaya diri.

\section{Referensi}

[1] Alim, Sahirul. Sains, Teknologi dan Islam. Yogyakarta: Titian Ilahi, 1998.

[2] Fahruddin, M. Mukhlis. Pusat Peradaban Islam Abad Pertengahan: KasusBayt al Hikmah .Jurnal el Harakah. Vol. 11.No. 3. 2009.

[3] Fathani, Abdul Halim. Matematika Hakikat dan Logika. JogJakarta: Ar-ruzz Media, 2009.

[4] Griffits, H. B and A.G Howson, Mathematic: Society and Curricula, Cambridge University Press, 1974.

[5] Hasyim, Farid. Ilmu Pengetahuan dan Perkembangannya: Tantangan Kemajuan dan Kemunduran Dunia Islam .U/ul Albab Jurnal Studi Islam.Vol. 13. No. 1. 2012.

[6] Herawati. Agustinus: Potret Sejarawan Masa Pertengahan dan Kontribusi Bagi Kajian Sejarah Islam . Jurnal Thaqafiyyat. Vol. 13. No. 1. 2012.

[7] Hitti, Philip K. History of The Arabs. Jakarta: PT Serambi Ilmu Semesta, 2014.

[8] Laksono, Eko. Imperium III; Zaman Kebangkitan Besar. Jakarta: Hikmah, 2010.

[9] Mohamed, Mohaini. Matematikawan Muslim Terkemuka. Jakarta: Salemba Terkini, 2004.

[10] Muhsetyo, Gatot. Gagasan $(\mathrm{HCN}+\mathrm{K})$ untuk Pengembangan Model Pembelajaran Matematika dalam Kompetisi Global.Karya Tulis disampaikan dalam Sidang Terbuka Senat Universitas Negeri Malang, Malang, 2012.

[11] Nakosteen, Mehdi. Kontribusi Islam atas Dunia Intelektual Barat. Surabaya: Risalah Gusti, 1996.

[12] Nizar, Samsul. Sejarah Pendidikan Islam. Jakarta: Kencana, 2007.

[13] Rifai, Agus. Perpustakaan Islam. Jakarta: PT RajaGrafindo Persada, 2014.

[14] Sukardjono. Hakikat dan Sejarah Matematika. Jakarta: Universitas Terbuka, 2011.

[15] Sunanto, Musyrifah. Sejarah Islam Klasik: Perkembangan I/mu Pengetahuan Islam. Jakarta: Kencana, 2011.

[16] Supriyadi.Renaisans Islam. Jakarta: PT Gramedia, 2015.

[17] Suyanta, Sri. Transformasi Intelektual Islam ke Barat, Jurnal I/miah Islam Futura. Vol. X, No. 2, 2011.

[18] Wikipedia, Sejarah Matematika, diakses dari https://id.wikipedia.org/wiki/Sejarah_ matematika pada tanggal 15 Juni 2015; Online. 